\title{
Nordafrika efter de folkliga revolterna - tillbaka till ordningen!
}

\author{
CHRISTIAN ANDERSSON
}

Envälde vilar ytterst på bajonetterna. Men enbart våld räcker i allmänhet inte för en regim som vill behålla makten. Den kan mörda sina medborgare, men i längden är det en ohållbar strategi om den inte väljer att isolera sig från omvärlden som Kim-dynastin. Den behöver skaffa sig någon form av berättigande eller åtminstone acceptans genom att knyta an till medborgarnas grundläggande normer och värderingar. Det kan kallas för att skaffa sig "legitimitet”. Här är inte platsen för en filosofisk eller semantisk analys av begreppet, men i det här sammanhanget innehåller det mer än den ursprungliga betydelsen av franskans légitimité, "laglighet" eller "arvsrätt". Antologin Politics and Society in the Contemporary Middle East använder begreppet i betydelsen av makthavarens strategier på olika fält för att bli accepterad, både av de egna medborgarna och av omvärlden. Redaktören skriver till exempel om hur Israels framgångar i krigen 1948 och 1967 "undergrävde legitimiteten för regimerna i Mellanöstern - särskilt enpartirepublikerna" (Angrist 20I9, s. 22, min övers.). Området som ibland kallas MENA (Middle East and North Africa) domineras av autokratier (självhärskare) utan den liberal-demokratiska legitimitet som bygger på fria val, yttrandefrihet och rättsstat. Då blir alternativa strategier avgörande för regimers långsiktiga överlevnad. I ovan nämnda antologis första del ges en utförlig genomgång av de olika fält som regimer kan spela på i sin legitimitetsstrategi, i betydelsen av initiativ som kan skapa stöd och acceptans i befolkningens och omvärldens ögon. 
- "Spökdemokrati" via lagar och politiska institutioner: till exempel genom en konstitution som på pappret garanterar fria val och medborgerliga rättigheter.

- Internationella relationer: till exempel genom allianser med resursstarka makter eller populära konflikter som med Israel, före detta kolonialmakter eller rivaliserande grannländer.

- Politisk ekonomi: till exempel genom subventioner av baslivsmedel, minimilöner eller speciella favörer för nyckelgrupper som politiker, poliser och militärer.

- Civila samhället: till exempel genom stöd och favörer till regimtrogna rörelser och trakasserier av regimkritiska.

- Religion: till exempel genom byggande av moskéer, förbud mot alkohol och omoral, ojämlik kvinlig arvsrätt.

- Identitet: som ovan samt till exempel genom ett utbildningsväsen på arabiska och ett förhärligande av den förkoloniala "nationen" och den antikoloniala kampen.

Autokratierna i Mellanöstern och Nordafrika har funnits ända sedan självständigheten från kolonialmakterna efter andra världskriget. En värld som är mer integrerad när det gäller ekonomi, kommunikationer och miljö har tvingat fram komplexa legitimitetsstrategier. Jag ska försöka illustrera detta med den senaste utvecklingen i de tre Maghrebländerna Algeriet, Marocko och Tunisien. De är alla tre arabisktalande och förstår i stort sett varandras dialekter, darja. De har en stor minoritet av tamazight-talande (berberspråk), särskilt Marocko, som också använder alfabetet tifinagh i officiella sammanhang. De har alla tre islam inskrivet i konstitutionen. De har alla varit fransk koloni (Algeriet) eller protektorat (Tunisien och Marocko) och den politiska eliten kommunicerar fortfarande på franska, om än inte lika mycket som för ett halvsekel sedan. De har ungefär samma utvecklingsnivå mätt i BNP per capita, samma höga arbetslöshet, särskilt bland ungdomar. De är alla tre autokratier, av olika valör och med olika legitimitetsstrategier. 


\section{Algeriet}

Den algeriska nationella befrielsefronten FLN utkämpade ett sju och ett halvt år långt krig mot kolonialmakten Frankrike, från allhelgonadagen 1954 till Évianfördraget den I8 mars 1962, som banade vägen för självständighet den I juli samma år. Den provisoriska algeriska regeringen GPRA utmanövrerades snabbt av algeriska styrkor som bidat sin tid i Marocko, ledda av den så kallade Oujdaklanen med bland annat överste Houari Boumedienne och Abdelaziz Bouteflika. Efter ytterligare en kupp styrde sedan Boumedienne landet enväldigt i nästan femton år, förstatligade olje- och gastillgångarna och arabiserade undervisningen. Formellt styrdes landet av ett revolutionsråd med befrielsefronten som alibi. Men FLN tilläts aldrig sammankalla till partikongress. Först efter Boumediennes död 1978 fick FLN en mer aktiv roll som politiskt parti. Ungdomsprotester hösten 1988 mynnade ut i "den algeriska våren" 1989 med flerpartisystem, självständiga medier och fackföreningar, allmänna val till kommuner, regioner och parlament. Den internationella konjunkturen, sjunkande oljepriser och östblockets sammanbrott, gynnade de krafter som arbetade för systemskifte.

Men när islamisterna höll på att vinna i demokratiska val ingrep militären på nytt. 1990-talet blev "det svarta decenniet" med våldsamma väpnade sammandrabbningar mellan militären och olika militanta jihadistgrupper. Till slut kallade militären hem Abdelaziz Bouteflika från landsflykten och gjorde honom till president. Han genomdrev långtgående amnesti och använde stigande gas- och oljeinkomster för insatser som skapade social stabilitet (Andersson 2020, s. 98). Men när resurserna sinade och den slagrörde Bouteflika försökte ställa upp för en femte presidentperiod våren 2019, utbröt gatuprotester som tvingade militären att släppa Bouteflika (han avled 202I). Rörelsen Hirak samlade hundratusentals protesterande i de större städerna under paroller som "Civil stat, inte militär!" (Andersson 2020, s. 95-I05). Pandemin och regimens repression krossade rörelsen. Militären utsåg en ny presidentkandidat som segrade i ett presidentval med under 40 procents valdeltagande. I det följande parlamentsvalet, sommaren 202I, var valdeltagandet officiellt 23 procent. I det oppositionella Kabylien var det praktiskt taget noll. 
Muslimska brödraskapets parti MSP blev näst största parti efter FLN men släpptes inte in i regeringen (där partiet suttit 1996-2012). Regimen har återgått till en beprövad legitimitetsstrategi: polemik med den före detta kolonialmakten Frankrike om befrielsekrigets skuld och historieskrivning och till den gamla konflikten med Marocko.

\section{Marocko}

Den marockanska monarkin stammar från en alaouitisk dynasti som dominerat landets politiska liv sedan I600-talet. Den vilar på en stark historisk och religiös legitimitet. Den nuvarande kungens farfar, Muhammed V, tvingades i exil av fransmännen på I950-talet men lyckades ändå framgångsrikt förhandla fram landets självständighet 1956. Fadern, Hassan II, var en despot av värsta sorten som spärrade in hundraals politiska motståndare under vedervärdiga förhållanden och mördade sina politiska motståndare. Hans största bragd var att överleva två våldsamma militärkupper. Man kan kanske säga att han dog en naturlig död 1999 tack vare Västsahara, som han lät invadera 1975 efter det att Spanien lämnat sin gamla koloni. Kravet på Marockos historiska rätt till Västsahara var populärt både bland allmänheten och militären. Ett utdraget krig fördes under många år mot befrielserörelsen Polisario, som fick stöd av Algeriet.

Efter en längre period av relativt lugn har den konflikten blossat upp igen. Orsaken till det är både utrikespolitisk och inrikespolitisk. President Trump fick Marocko att erkänna Israel mot att USA erkände Marockos rätt till Västsahara, en fråga som i decennier väntat på resultatet av en folkomröstning som aldrig blivit av (efter en FN-resolution från I99I). I början av november 202I genomförde Marocko en drönarattack som dödade tre algeriska lastbilschaufförer på ökenvägen mellan Algeriet och Mauretanien, öster om den sandvall som Marocko rest som mur mot Algeriet och Polisario (Le Monde 4 november 202I). Algeriet har hotat med repressalier. Gränsen mellan de båda länderna har varit stängd sedan I990-talet till stor skada för den regionala ekonomiska utvecklingen.

Även i Marocko demonstrerade tusentals medborgare mot det politiska systemet våren 201 inom ramen för 20-februarirörelsen (El-Ghobashy \& 
Angrist 20I9, s. 5I). Den tvingade monarken till vissa eftergifter, bland annat en ny konstitution som låter premiärministern utses av parlamentet i stället för av kungen. I valet 20 II gick oppositionen i islamistiska Rättvise- och utvecklingspartiet starkt framåt och kunde bilda regering, men med en handlingsfrihet begränsad av kungamaktens övergripande samhällskontroll. I valet 202I (med ett officiellt deltagande på över 50 procent) fick det bara några enstaka mandat (Le Monde I3 september 202I). De kungatrogna elitpartierna (makhzen) vann valet. Den traditionella politiska ordningen var återställd.

\section{Tunisien}

"Hur i all världen kan ett utbildat samhälle som det tunisiska, integrerat i en komplex världsekonomi med en utbredd medelklass, i åratal tolerera en så brutal och korrumperad polisstat som Ben Alis?” Nordafrikaspecialisten Luis Martinez (2019, s. 59, min övers.) är inte den ende som förvånas. Den tunisiska revolten mot diktatorn Ben Ali är full av paradoxer. Ben Ali och hans familj var skurkar i Bokassa-klass, ja värre, eftersom det fanns betydligt mer att sko sig på i Tunisien på 2000-talet än i Centralafrikanska republiken på 1970-talet. Presidentfamiljens förmögenhet uppskattades till 20 miljarder euro (Piot 20II, s. 137). Den dåvarande säkerhetschefen Ben Ali grep makten i en kupp 1987 och behöll den i 24 år.

Den I7 december 2010 satte den 26-årige gatuförsäljaren Mohammed Bouazizi eld på sig själv utanför kommunhuset i Sidi Bouzid som protest mot myndigheternas trakasserier. Han avled av sina skador i början av januari 20Ir. Det utlöste omfattande demonstrationer mot regimen. Den I4 januari lämnade familjen Ben Ali landet med flyg till Jedda. Viktiga faktorer bakom den framgångsrika folkliga revolten var att militärledningen vägrade krossa protesterna och att landet har relativt starka oberoende civila organisationer. Den tunisiska "dialogkvartetten" som bestod av landets fackliga landsorganisation, arbetsgivarorganisation, förbund för mänskliga rättigheter och advokatförbund fick Nobels fredspris 2015 .

Steg för steg kravlade sig Tunisien sedan upp för människorättsorganisationernas demokratistege, "en anmärkningsvärd - om än skakig - 
övergång till demokrati” (Angrist 2019, s. 8, min övers.). Att övergången skulle bli just "skakig" stod klart för de flesta bedömare med tanke på de stora sociala skillnaderna i landet, särskilt mellan de mer utvecklade kuststäderna och det fattigare inlandet (Laroussi 202I). Det nya politiska landskapet kännetecknades av stor splittring, djupa personliga motsättningar och kompromisslösa partier. Det enda parti som klarat sig någorlunda genom tre parlamentsval är Muslimska brödraskapets tunisiska variant An-nahda ("Renässans"), som visserligen fallit från 37 procent 201 till 20 procent 2019 men som ingått i alla regeringar sedan demokratins införande.

Den 25 juli 202I tog det slut. Landets president Kaïs Saïed utlyste undantagstillstånd, avsatte regeringen och stängde parlamentet. De politiska partierna har enligt presidenten svikit revolutionen och utsatt landet för "omedelbar fara", vilket skulle utlösa den nödparagraf i konstitutionen som ger presidenten fria händer under en begränsad period. Presidenten, som annars mest har en ceremoniell funktion, kan då styra direkt genom dekret. De politiska partierna och människorättsorganisationerna varnar för att han är på väg att återskapa diktaturen. Den före detta assistenten i islamisk rätt vid universitetet i Tunis tycks ha stöd hos stora delar av befolkningen, som tröttnat på de politiska partiernas käbbel och handlingsförlamning. Le Mondes Nordafrikaexpert skriver att Kaïs Saïed har inspirerats av Egyptens marskalk al-Sisi, som krossade Muslimska brödraskapet där 20I3 (Le Monde 26/27 september 202I). Presidentens retorik har sedan i somras blivit allt mer populistisk. Han rasar mot sina fiender, kallar dem "förrädare" och "tjuvar". Han förespråkar direktdemokrati på personlig grund i stället för allmänna val och politiska partier. Han säger sig vara den som representerar "det verkliga folket" och "folkviljan" och tänker revidera den liberal-demokratiska konstitutionen från 20I4, vilket egentligen bara parlamentet kan göra. Det är en populism som man kan känna igen från högernationalistiska rörelser runt om i världen. 


\section{Slutsatser}

Trots stora likheter när det gäller kolonialhistoria, språk och kultur mellan Tunisien, Algeriet och Marocko har autokrater i de tre länderna haft helt olika strategier för att legitimera sina envälden. Marocko är en gammal monarki, som hävdar en släktlinje ända tillbaka till Profeten ("de troendes anförare"). Landet saknar olja, vilket gör att makten valt en något mer sofistikerad politisk strategi. Politiska och medborgerliga rättigheter har getts något större utrymme, vilket legat i linje med landets ekonomiska och militära beroende av västmakterna (Bank, Richter \& Sunik 20I4). I Algeriet har oljeinkomsterna gjort att statskassan haft råd att stilla folkligt missnöje med mer pengar till infrastruktur, utbildning och subventioner av levnadsvillkor. Dessutom finns stöd för politisk stabilitet efter "det svarta decenniets" mardrömmar. Tunisiens demokratiska framtid är oklar men kanske ändå ljusare än grannarnas med tanke på civilsamhällets styrka och militärens historiska distans till politiken.

En viktig förklaring till de olika strategierna i de tre länderna är just skillnader i det militära inflytandet över samhällsutvecklingen. Algeriet fördubblade sina militärutgifter mellan 2010 och 2020 , från 3,5 till 6,7 procent av BNP, i särklass högst i Afrika. Marocko ökade samtidigt sina försvarsutgifter från 3,4 till 4,3 procent av BNP, Tunisien från I,3 till 2,9 procent, delvis förklarat av ökade kostnader för gränsskyddet mot det turbulenta Libyen (SIPRI 2020). Särskilt i Algeriet vilar regimen på ett uttalat repressivt hot mot kritiker och oppositionella. Det är samma hot som funnits där ända sedan befrielsekampen: tag er i akt, annars - bajonett på!

\section{Referenser}

Andersson, Christian (2020) "'Arabiska våren 2' - helt inställd eller bara i karantän?”, i Arkiv. Tidskrift för sambällsanalys, nr I2, s. 95-106.

https://doi.org/I0.13068/2000-6217.I2.KI

Angrist, Michele Penner (2019) "The Making of Middle East Politics”, i Angrist, Michele Penner (red.), Politics and Society in the Contemporary Middle East.

London: Lynne Rienner Publishers.

Bank, André, Richter, Thomas \& Sunik, Anna (2014) "Durable Yet Different: Monarchies in the Arab Spring", i Journal of Arabian Studies, volym 4, nr 2, s. I63-179. https://doi.org/IO.IO80/21534764.20I4.971647 
El-Ghobashy, Mona \& Angrist, Michele Penner (2019) "Governments and Oppositions", i Angrist, Michele Penner (red.), Politics and Society in the Contemporary Middle East. London: Lynne Rienner Publishers.

Laroussi, Houda (202I) La Tunisie en crises. Tensions et conflits locaux en contexte postrévolutionnaire. Paris: L'Harmattan.

Le Monde I3 september 202I, "Au Maroc et en Tunisie, l'islam politique subit de sévères déconvenues" av Frédéric Bobin. https://www.lemonde.fr/afrique/ article/202I/og/13/au-maghreb-les-severes-deconvenues-de-l-islamisme-de-gouvernement_6094435_3212.html (I5 november 202I)

Le Monde 26/27 september 202I, ”Tunisie. Le séisme Kaïs Saíed” av Frédéric Bobin.

Le Monde 4 november 202I, "Sahara occidental: le risque d'une escalade entre le Maroc et l'Algérie" av Frédéric Bobin. https://www.lemonde.fr/afrique/ article/202I/II/O4/sahara-occidental-le-risque-d-une-escalade-entre-le-maroc-et-1algerie_6I00872_32I2.html (4 november 202I)

Martinez, Luis (2019) L’Afrique du Nord après les révoltes arabes. Paris: Presses de Science Po.

Piot, Olivier (20II) La révolution tunisienne. Dix jours qui ébranlèrent le monde arabe. Paris: Les petits matins.

SIPRI (2020) SIPRI Military Expenditure Database. https://www.sipri.org/databases/ milex (II november 202I) 


\section{Moderna klassiker}

\section{Michel Foucault \\ Övervakning och straff}

\section{Arkiv förlag}

Varför intar fängelset en så dominerande plats i dagens straffsystem? Den frågan står i centrum för Michel Foucaults Övervakning och straff (Surveillir et punir), den kanske mest inflytelserika i hans långa rad av civilisationskritiska undersökningar. I ett språk som vibrerar av patos och inlevelse med de förtryckta och plågade illustrerar Foucault sina teser med skakande inblickar i straffets och disciplineringens historia. Denna klassiker finns sedan 2017 i en femte översedd och ombruten svensk upplaga som för första gången innehåller illustrationerna ur den franska originalutgåvan.

Översättning C G Bjurström, 422 sidor

„Läs mer om boken på www.arkiv.nu« 


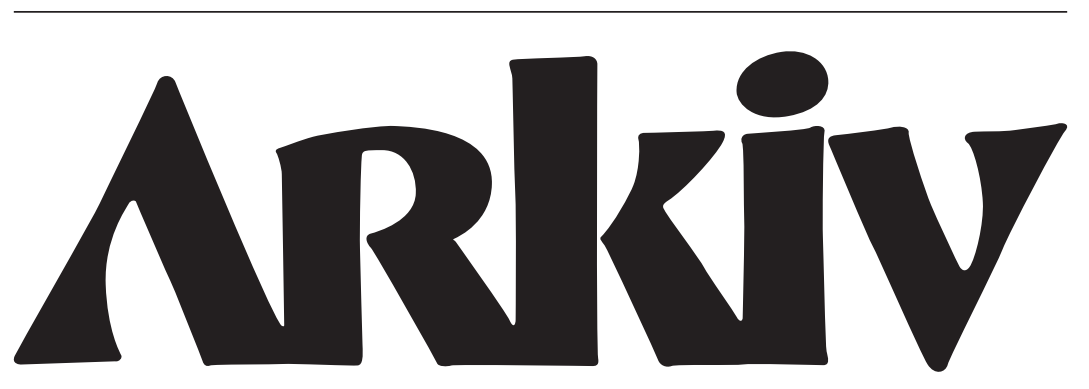

TIDSKRIFT FÖR SAMHÄLLSANALYS · NR 7

\section{Från perestrojka till Bolotnaja}

Utvecklingen av ett ryskt civilsamhälle

I vårt temanummer om det ryska civilsamhällets utveckling under de senaste 30 åren, från Sovjetunionens fall till dagens situation under Putins regim, har tidskriftens redaktör Zhanna Kravchenko fătt fyra ryska akademiker att bidra med nyskrivna texter.

INNEHÅLL:

Zhanna Kravchenko, "Inledning"

Aleksandr V. Šubin, ”Den sensovjetiska sociala mobiliseringen: neformaly-rörelsen under perestrojkan"

Carine Clément, "Arbetarmobiliseringen i Ryssland från slutet av i980-talet till i dag"

Aleksej Sachnin, "Bolotnajarörelsen: politisk kultur, identitet och mobilisering"

Oleg Žuravlev, ”Vad blev kvar av Bolotnajatorget? En nystart för den lokala aktivismen i Ryssland" 